\title{
Australian Journal of Crop Science \\ Biomass yield, nutritional status and industrial quality of sugarcane as a function of nitrogen and potassium fertilization
}

\author{
Mauro Wagner de Oliveira ${ }^{1}$, Christiano Nascif ${ }^{2}$, Vinicius Santos Gomes da Silva ${ }^{1}$, Terezinha Bezerra Albino \\ Oliveira ${ }^{1}$, Thiago Camacho Rodrigues ${ }^{2}$, Keite Fernandes Vieira Gama ${ }^{1}$, and Gabriel Carlos Benhami de \\ Oliveira $^{2}$
}

\author{
${ }^{1}$ Universidade Federal de Alagoas, Centro de Ciências Agrárias, Rio Largo, Alagoas, Brazil \\ ${ }^{2}$ Programa de Desenvolvimento da Pecuária Leiteira da Região de Viçosa- MG (PDPL-RV), Viçosa, Minas Gerais, \\ Brazil
}

*Corresponding author: vinicius.agro2008.1@gmail.com

\begin{abstract}
Sugarcane plant uptakes a large amount of nutrients from the soil. Thus, crop yield may decrease due to the reduced availability of nutrients in the soil. The aim of this study was to evaluate plant nutritional status, yield and juice quality of variety RB867515 in the first regrowth cycle, fertilized with doses of nitrogen and potassium. Therefore, a study was set up in a randomized complete block design (RCBD) with four replicates. The following treatments were applied to the first regrowth sugarcane: $\left(T_{1}\right)$ control: no nitrogen $(\mathrm{N})$ and potassium (K) fertilization; $\left(\mathrm{T}_{2}\right) \mathrm{N}$ and $\mathrm{K}$ fertilization, replenishing $75 \%$ of the $\mathrm{N}$ and $\mathrm{K}$ removed by cane-plant harvest; $\left(\mathrm{T}_{3}\right) \mathrm{N}$ and $\mathrm{K}$ fertilization, replenishing $100 \%$ of the $\mathrm{N}$ and $\mathrm{K}$ removed by the cane-plant harvest; $\left(\mathrm{T}_{4}\right) \mathrm{N}$ and $\mathrm{K}$ fertilization, replenishing $125 \%$ of the $\mathrm{N}$ and $\mathrm{K}$ removed by the cane-plant harvest. The increase in the fertilizer dose promoted a linear effect in leaf $\mathrm{N}$ content and biomass of $\mathrm{N}$ and $\mathrm{K}$ concentration, but did not influence the quality of the juice, which had average concentrations of 22.23; 19.63; 88.30 and 16.50 (Brix, Pol, Purity and PC, respectively). TRS was also not influenced by fertilization, with an average value of $162.82 \mathrm{~kg} \mathrm{t}^{-1}$. Biomass yield increased linearly with fertilization, yielding the regression equation of $Y=82.74+0.3394 x$, with $R^{2}$ of 0.9824 . The values obtained indicated excellent quality sugarcane.
\end{abstract}

Keywords: Saccharum spp., nutrient content, nutritional efficiency, uptake, plant nutrition.

Abbreviations: Brix_soluble solids; Pol_apparent sucrose in the juice; Purity_ juice purity; PC_apparent sucrose in the cane; TRS_ total recoverable sugars.

Introduction

Brazil's sugarcane industry is one of the most competitive in the world, mainly due to the development of national science and technology for the production of sugarcane. The country is also developed in knowledges of extraction and industrialization of the juice, the use of sugar-alcohol residues in sugarcane fertilization and the generation of electricity (Pina et al., 2015; Oliveira et al., 2017; Pereira et al., 2017; Silva et al., 2017b). As a result of its high biomass production, sugarcane plant uptakes and accumulates high amounts of soil nutrients, especially $\mathrm{N}$ and $\mathrm{K}$, which are generally removed in larger amounts (Oliveira et al., 2007; Prellwitz and Coelho, 2011). Nitrogen is found in only $1 \%$ of the total dry mass of the plant, but its deficiency causes reduced synthesis of chlorophyll, essential amino acids and energy required to produce carbohydrates and carbon skeletons, directly reflecting crop development and yield (Canfield et al., 2010; Marschner, 2012; Bloom, 2015). On the other hand, potassium is involved in the regulation of tissue turgidity, enzymatic activation, opening and closing of the stomata, carbohydrate transport, transpiration, and resistance to frosts, drought, diseases and bedding (Flores et al., 2012; Marschner, 2012; Cardin et al., 2016).
Oliveira et al. (2016) found average uptake (extraction) values of 1.69 and $1.21 \mathrm{~kg} \mathrm{t}^{-1}$ of stalk for the $\mathrm{N}$ and $\mathrm{K}$, respectively, when studies 11 sugarcane varieties. The high accumulation of these elements by the sugarcane highlights the need to adequately manage fertilization to restore these nutrients so that the yield and the longevity of the regrowth are not compromised.

Considering that the extraction of soil nutrients by sugarcane is high, adequate fertilizer management is essential for the crop to reach high yields. Furthermore, fertilization represents a significant percentage of the production costs of sugarcane agriculture; thus, it must follow strict criteria for optimization to obtain higher yield at lower costs (Clemente et al., 2017; Silva et al. 2017a).

The correct management of fertilization is fundamental to make sugarcane activity more competitive and profitable, as it represents a significant percentage of sugarcane production costs (Oliveira et al., 2007). The amounts of applied fertilizers are usually based on studies of crop response to fertilization, soil fertility, or more currently, to expected yield and soil fertility. Another possibility is replenishment fertilization, which is the replacement of 
nutrients extracted by the harvest (Oliveira et al., 2007; Silva et al., 2017a).

In this study, we evaluated nutrient status, juice quality, nutrient content in shoot biomass and biomass yield of variety RB867515 in the first ratoon cycle as a function of replenishment doses of nitrogen and potassium.

\section{Results and Discussion}

\section{Nutritional status of sugarcane}

Table 1. shows the results of the analysis of variance and the means of macro and micronutrient contents in leaf. There was a significant effect of nitrogen and potassium fertilization only for $\mathrm{N}$, whose leaf content increased linearly with fertilization dose (Figure 1).

The mean values, values of nutrient contents in +3 leaf of RB867515 are presented in Figure 2. The minimum and maximum values have been calculated as reference for comparison, based on the studies of Malavolta et al. (1997), Oliveira et al. (2007) and Raij (2011). The analysis of these figures shows that there was minor phosphorus deficiency, but moderate potassium deficiency for the macronutrients, even in the $125 \%$ replenishment fertilization (T4 with max replenishment). These results reflect the low levels of phosphorus and potassium in the study area (Table 4). Phosphorus contents at $0-20$ and $20-40 \mathrm{~cm}$ were only 2.0 and $0.80 \mathrm{mg} \mathrm{dm}^{-3}$ of soil, respectively. The application of 100 $\mathrm{kg}$ of $\mathrm{P}$ (equivalent to $229 \mathrm{~kg}$ of $\mathrm{P}_{2} \mathrm{O}$ ) was not enough to ensure adequate phosphorus supply for the first regrowth. The low initial $P$ content in soil ( 15.0 and $7.0 \mathrm{mg} \mathrm{dm}^{-3}$ ) also contributed to moderate potassium deficiency.

Sugarcane removes large quantities of phosphorus and potassium (Oliveira et al., 2010), with values of approximately $0.2 \mathrm{~kg} \mathrm{P}$ and $1.5 \mathrm{~kg} \mathrm{~K}$ per ton of fresh matter (Oliveira et al., 2007). Thus, cultivation practices that allow greater deepening of the sugarcane root system should be adopted, aiming to further explore soil volume and also increase the availability of these nutrients in the soil by chemical and organic fertilization (Caione et al., 2011; Ernani et al., 2011).

In sugarcane fields with good phosphorus and potassium supply, leaf contents have ranged from 2.0 to $3.0 \mathrm{mg}$ of $\mathrm{P} \mathrm{kg}$ 1 and 13.0 to $16.0 \mathrm{mg}$ of $\mathrm{K} \mathrm{kg}^{-1}$ of leaf blade dry matter (Oliveira et al., 2007). However, sugarcane plantations with good regrowth yield have shown lower leaf contents than the minimum defined by Malavolta et al. (1997), Oliveira et al. (2007) and Raij (2011). This is also illustrated in the results of Mendes (2006), who evaluated $P$ and $K$ leaf contents in eight varieties of sugarcane, all of which are widely used (including RB867515), in which the leaf contents ranged from 1.3 to $1.6 \mathrm{mg} \mathrm{kg}^{-1}$ and 9.2 to $13.1 \mathrm{mg} \mathrm{kg}^{-1}$ for phosphorus and potassium, respectively. However, the accumulation of biomass ranged from $83 \mathrm{t} \mathrm{ha}^{-1}$ in RB855536 to $113 \mathrm{t} \mathrm{ha}^{-1}$ in RB867515. Another example was reported by Oliveira et al. (2014) in a study conducted in Nanuque, northeast of the state of Minas Gerais, Brasil. These authors found that the potassium content in the leaf blade of RB867515 was $9.20 \mathrm{~g} \mathrm{~kg}^{-1}$, and consequently insufficient according to Malavolta et al. (1997), Oliveira et al. (2007) and Raij (2011). Meanwhile, biomass yield reached $155 \mathrm{t}$ of fresh matter per hectare.

\section{Nutrient concentration in biomass}

Table 2 shows the results of the analysis of variance and the mean contents of macro and micronutrients in the shoot biomass of the first regrowth sugarcane. There was significant and linear effect of $\mathrm{N}$ and $\mathrm{K}$ fertilizer doses only for $\mathrm{K}$ and $\mathrm{N}$ concentrations (Table 3 ).

The increase in $\mathrm{N}$ and $\mathrm{K}$ biomass content was due to the increased availability of these elements in the soil solution, due to fertilization. Sugarcane is a crop that can be used for feeding purposes but it is interesting to note that this plant has nutritional limitations due to low levels of protein, phosphorus and sulfur. However, fertilization can improve nutritional quality of sugarcane. Calheiros et al. (2012) reported that the increase in phosphorus dose $(0,30,60,90$, 120 and $150 \mathrm{~kg}$ per hectare) applied at the bottom of the planting groove influenced the accumulation of dry matter and sucrose, with a quadratic effect. There was a linear but discrete effect of the $P$ doses on the concentration of this element in dry matter, but this was not observed for crude protein concentration. On the other hand, protein and phosphorus accumulation were significantly influenced by fertilization.

In this study, the crude protein values were insufficient to ensure good functioning of the rumen even at the maximum dose of replenishment fertilization (125\%) (Calheiros et al., 2012). The protein contents of $40.0 \mathrm{~g} \mathrm{~kg}^{-1}$ were obtained at $125 \%$ replenishment fertilization, considering value of 6.25 for the transformation factor of $\mathrm{N}$ into crude protein. For exclusive sugarcane diets (Calheiros et al., 2012) crude protein content should be between 60.0 and $70.0 \mathrm{~g} \mathrm{~kg}^{-1}$ (Lima et al., 2012). However, several studies conducted by Brazilian researchers have shown a wide variation in the crude protein content in shoot biomass of sugarcane, with values ranging from 20.0 to $43.0 \mathrm{~g} \mathrm{~kg}^{-1}$ of biomass dry matter (Fernandes et al., 2001; Mendes, 2006; Franco et al., 2007). Another possible alternative to raise the protein content of sugarcane is nitrogen fertilization (Calheiros et al., 2012). However, in a study on fertilization with doses of $0,80,150$ and $300 \mathrm{~kg}$ of $\mathrm{N}$ per hectare per year, Salas et al. (1992) found that fertilization caused minor changes in the nutritional value and there was a great influence of sugarcane age/maturity on protein content. The maximum protein content $\left(33.7 \mathrm{~g} \mathrm{~kg}^{-1}\right)$ was observed in six-month-old plants, coinciding with that reported by Lima and Mattos (1993). At the highest fertilization dose (300 kg N + $375 \mathrm{~kg} \mathrm{~K}$ per hectare) used in this study, the protein content increased by approximately $90 \%$ (from 21.12 to $40.0 \mathrm{~g}$ per $\mathrm{kg})$.

\section{Quality of stalks and juice}

Table 3. shows the results of the analysis of variance for soluble solids content in the juice, percentage of apparent sucrose in the juice, purity, percentage of apparent sucrose in the stalk, fiber of the industrial stalks, total recoverable sugars and forage yield in tons of fresh matter per hectare of RB867515 in the first regrowth cycle. By analyzing this table, we found that even with very low coefficients of variation (lower than $8.0 \%$ ) the replenishment fertilization only influenced the accumulation of fresh matter. In a study 
Table 1. Analysis of variance of macro and micronutrient contents in +3 leaf of sugarcane as a function of nitrogen and potassium fertilization.

\begin{tabular}{lllllll}
\hline & $\mathrm{N}$ & $\mathrm{P}$ & $\mathrm{K}$ & $\mathrm{Ca}$ & $\mathrm{Mg}$ & $\mathrm{S}$ \\
Fertilization & $* *$ & $\mathrm{~ns}$ & $\mathrm{~ns}$ & $\mathrm{~ns}$ & $\mathrm{~ns}$ & $\mathrm{~ns}$ \\
Mean $\left(\mathrm{g} \mathrm{kg}^{-1}\right)$ & 20.50 & 1.45 & 8.00 & 7.80 & 3.35 & 3.00 \\
C.V.(\%) & 5.48 & 9.10 & 8.33 & 7.92 & 6.09 & 6,59 \\
\hline & $\mathrm{B}$ & $\mathrm{Cu}$ & $\mathrm{Fe}$ & $\mathrm{Mn}$ & $\mathrm{Zn}$ & \\
Fertilization & $\mathrm{ns}$ & $\mathrm{ns}$ & $\mathrm{ns}$ & $\mathrm{ns}$ & $\mathrm{ns}$ & \\
Mean $\left(\mathrm{mg} \mathrm{kg}^{-1}\right)$ & 6.15 & 5.50 & 83.50 & 145.00 & 11.00 & \\
C.V.(\%) & 25.89 & 19.44 & 3.70 & 13.28 & 11.37 & \\
\hline ns: not significant; * significant at $5 \%$ by the F-test. & & & &
\end{tabular}

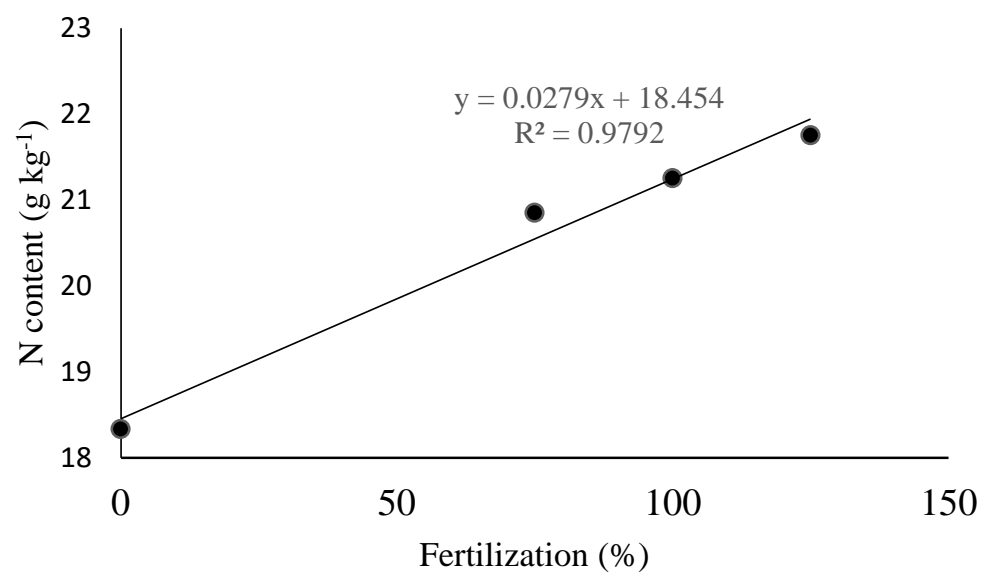

Fig 1. Nitrogen content in +3 leaf of sugarcane as a function of nitrogen and potassium fertilization.

Table 2. Analysis of variance of macro and micronutrient content in shoot biomass of sugarcane as a function of nitrogen and potassium fertilization

\begin{tabular}{lllllll}
\hline & $\mathrm{N}$ & $\mathrm{P}$ & $\mathrm{K}$ & $\mathrm{Ca}$ & $\mathrm{Mg}$ & $\mathrm{S}$ \\
Fertilization & $* *$ & $\mathrm{~ns}$ & $* *$ & $\mathrm{~ns}$ & $\mathrm{~ns}$ & $\mathrm{~ns}$ \\
Mean & 4.15 & 0.40 & 4.55 & 1.00 & 0.95 & 1.10 \\
C.V.(\%) & 4.71 & 12.74 & 11.12 & 9.34 & 11.40 & 11.81 \\
\hline & $\mathrm{B}$ & $\mathrm{Cu}$ & $\mathrm{Fe}$ & $\mathrm{Mn}$ & $\mathrm{Zn}$ & \\
Fertilization & $\mathrm{ns}$ & $\mathrm{ns}$ & $\mathrm{ns}$ & $\mathrm{ns}$ & $\mathrm{ns}$ & \\
Mean & 2.25 & 18.27 & 109.00 & 48.00 & 6.50 & \\
C.V.(\%) & 10.09 & 1.50 & 16.32 & 16.82 & 18.29 & \\
\hline
\end{tabular}

ns: not significant; ${ }^{*}$ significant at $5 \%$ by the F-test.
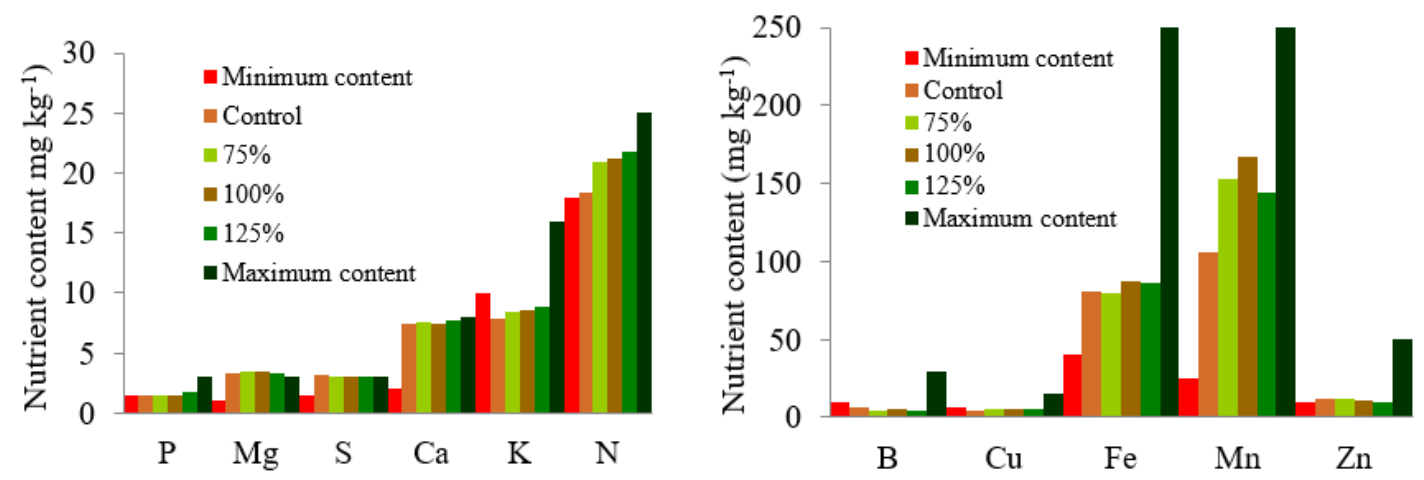

Fig 2. Mean values of macro and micronutrients leaf contents compared to the minimum and maximum levels reported in Brazilian literature. 
Table 3. Analysis of variance for technological quality of sugarcane as a function of nitrogen and potassium fertilization.

\begin{tabular}{|c|c|c|c|c|c|c|c|}
\hline & Brix & $\mathrm{POL}$ & Purity & PC & Fiber & TRS & Biomass yield \\
\hline Fertilization & ns & $\mathrm{ns}$ & ns & ns & ns & ns & $*$ \\
\hline & & 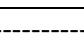 & $\%$ & - & & $\mathrm{kg} \mathrm{t}^{-1}$ & $\mathrm{t} \mathrm{ha}^{-1}$ \\
\hline Mean & 22.23 & 19.62 & 88.30 & 16.50 & 14.37 & 162.81 & 108.20 \\
\hline C.V.(\%) & 3.34 & 2.70 & 2.47 & 2.94 & 2.23 & 2.81 & 7.71 \\
\hline
\end{tabular}

ns: not significant; ${ }^{*}$ significant at $5 \%$ by the F-test.
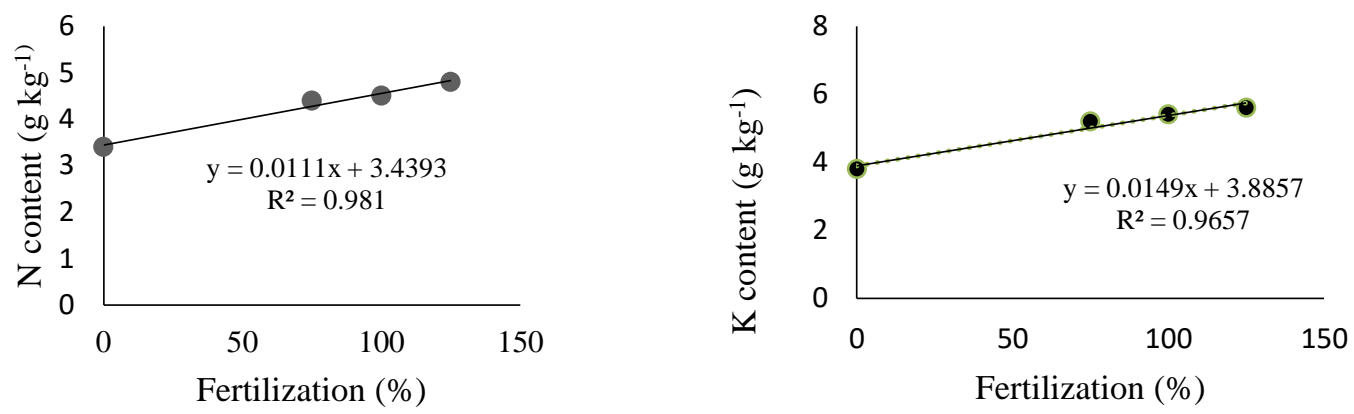

Fig 3. Nitrogen and potassium content in biomass of sugarcane as a function of nitrogen and potassium fertilization.

Table 4. Soil chemical characteristics.

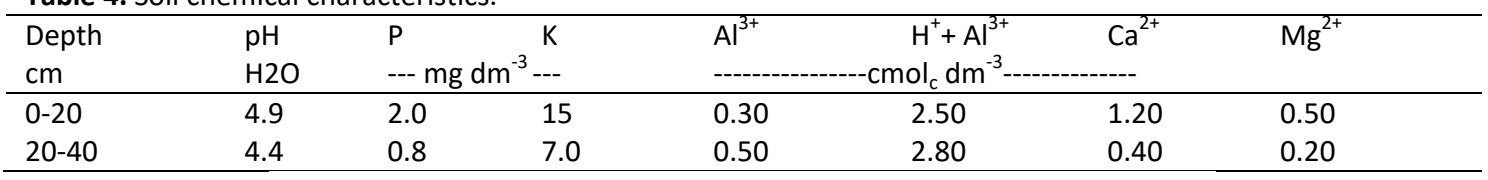

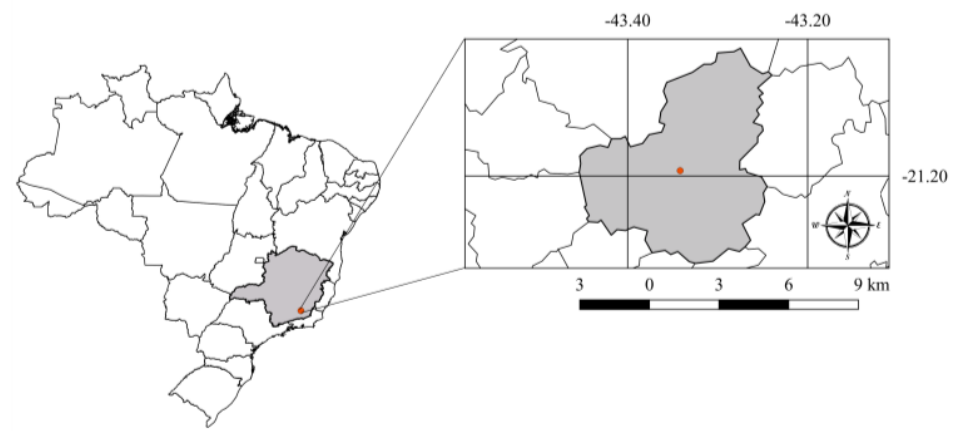

Fig 4. Location of the experimental area.

conducted by Calheiros et al. (2012), mean fiber percentages of 12.87 were observed for RB867515.

The sugarcane harvest happened after two months of low rainfall (Figure 1) in July. The low rainfall and the location of the study (slope area with more wind) may possibly have further dehydrated the sugarcane and raised the fiber content, in comparison to the study of Calheiros et al. (2012). The values of apparent sucrose have been reported for varieties of sugarcane grown in south-central Brazil, ranging from 19.0 to 22\% (Prado and Pancelli, 2006; Barbosa et al., 2007). According to Fernandes (2000) and Oliveira et al. (2014) these rangnes are indicators of good quality sugarcane.

The accumulation of fresh matter was positively related to the replenishment fertilization and the regression equation of $Y=82.74+0.3394 x$ was obtained, with $R^{2}$ of 0.9824 . The increase in forage yield at the maximum fertilizer dose was
$40 \mathrm{t}$ per hectare, which represents an increase of approximately $50 \%$ compared to the control treatment.

\section{Materials and Methods}

\section{Location and characteristics of the cultivation area}

The study was conducted in a field located in the city of Viçosa (200 45 '14 "S, 42 52' 55" W), Zona da Mata region of the state of Minas Gerais, Brazil (Figure 1). The climate of the region is tropical highland climate $(\mathrm{Cwb})$ with rainy summers and mild temperatures, according to Köppen classification. The average rainfall of the last 30 years is approximately $1,200 \mathrm{~mm}$. Rainfall during the experimental period is shown in Figure 2.

The soil of the experimental area was classified as Latossolo Vermelho-Amarelo distrófico (Embrapa, 2013). 
Prior to the study, soil sampling was done at $0-20 \mathrm{~cm}$ and 20-40 cm for chemical characterization. We determined $\mathrm{pH}$ $\left(\mathrm{H}_{2} \mathrm{O}\right), \mathrm{Ca}^{2+}, \mathrm{Mg}^{2+}, \mathrm{K}^{+}, \mathrm{Al}^{3+}$ and $\mathrm{P} . \mathrm{Ca}^{2+}, \mathrm{Mg}^{2+}$ and $\mathrm{Al}^{3+}$ were extracted with $1.0 \mathrm{~mol} \mathrm{~L} \mathrm{KCl}^{-1}$ and quantified by titration. The $\mathrm{P}$ and $\mathrm{K}^{+}$were extracted by Mehlich-1. The $\mathrm{P}$ was determined by colorimetry and $\mathrm{K}^{+}$by flame photometry. All analyses were done in accordance to the methodology described by Embrapa (2009) (Table 4).

Based on the results (Table 4), limestone and gypsum were used in sufficient quantity to raise base saturation to $60 \%$ in the topsoil and to reduce aluminum saturation in the subsurface layer, as proposed by Oliveira et al. (2007) and Raij (2011). The magnesium limestone was used, due to its availability in the region and also because $\mathrm{Mg}^{+2}$ content was above $0.40 \mathrm{cmol}_{\mathrm{c}} \mathrm{dm}^{-3}$ in the soil, considered critical by Oliveira et al. (2007) and Raij (2011).

After the application of limestone and gypsum, the soil was prepared with harrowing to incorporate the materials, followed by the opening the grooves.

\section{Plant material}

The variety RB867515 was planted in March 2013. We chose this cultivar because it is commonly representative in Brazil and constitutes the most planted variety in the most recent harvests (Silva et al., 2017a). Sugarcane stalks with three buds per seed piece were distributed in the planting grooves in order to reach 18 buds per meter. The cane-plant was fertilized with $100 \mathrm{~kg} \mathrm{ha}^{-1}$ of $\mathrm{P}$ (equivalent to $229 \mathrm{~kg}$ of $\mathrm{P}_{2} \mathrm{O}_{5}$ ) and $150 \mathrm{~kg} \mathrm{ha}^{-1}$ of $\mathrm{K}$. No nitrogen fertilizer was used in the planting.

Sixteen months after planting, the cane-plant was harvested at the time of maturation and the accumulation of dry matter and nutrients in the shoot biomass of the plant was evaluated, according to the method described by Malavolta et al. (1997) and Silva and Queiroz (2006). The mean values of nitrogen and potassium accumulation in cane-plant biomass were $240 \mathrm{~kg} \mathrm{~N}$ and $300 \mathrm{~kg} \mathrm{~K}$ per hectare. These values were used as reference for fertilizing the first sugarcane regrowth.

\section{Experimental design and treatments}

The study was conducted in a randomized complete block design with four replicates. It consisted of four treatments set up in the first regrowth sugarcane. The treatments consisted of: $\left(T_{1}\right)$ control: no nitrogen $(N)$ and potassium (K) fertilization; $\left(\mathrm{T}_{2}\right) \mathrm{N}$ and $\mathrm{K}$ fertilization, replenishing $75 \%$ of the nitrogen and potassium uptaken by the cane-plant harvest; $\left(\mathrm{T}_{3}\right) \mathrm{N}$ and $\mathrm{K}$ fertilization, replenishing $100 \%$ of the nitrogen and potassium removed by the cane-plant harvest; $\left(T_{4}\right) \mathrm{N}$ and $\mathrm{K}$ fertilization, replenishing $125 \%$ of the nitrogen and potassium removed by the cane-plant harvest. The plots consisted of five grooves of $5 \mathrm{~m}$ in length. All the plots were fertilized with phosphorus at a dose of $100 \mathrm{~kg}$ per hectare using simple superphosphate as a source of $P$, which is in line with that recommended by Oliveira et al. (2007) and Raij (2011). The amount of $\mathrm{N}$ and $\mathrm{K}$ applied in treatment $\mathrm{T}_{3}$ was 240 and $300 \mathrm{~kg}$ per hectare, respectively. The sources of nitrogen and potassium were ammonium sulphate and potassium chloride. Ammonium sulfate was chosen to avoid losses of $\mathrm{N}$ by volatilization of ammonia, since $\mathrm{N}$ and $\mathrm{K}$ fertilizers were applied to the soil surface (Oliveira et al., 2007; Raij, 2011).

\section{Nutritional status of sugarcane}

In the maximum growth stage of the first sugarcane regrowth, +3 leaves were collected to evaluate the nutritional status of the plants. For this purpose, we sampled the useful area of each plot, where 20 leaves were randomly collected. The sampled leaves were washed in running and deionized water. Afterwards, the middle third of the leaf blade was separated, discarding the central vein, for chemical analysis. Finally, the samples were dried at $65^{\circ} \mathrm{C}$ in a forced air oven to a constant weight and ground in Wiley type mill. The leaf blade was analyzed for nitrogen $(N)$, phosphorus $(\mathrm{P})$, potassium $(\mathrm{K})$, calcium $(\mathrm{Ca})$, magnesium $(\mathrm{Mg})$, sulfur $(\mathrm{S})$, boron $(\mathrm{B})$, copper $(\mathrm{Fe})$, manganese $(\mathrm{Mn})$ and zinc $(\mathrm{Zn})$ contents, according to the methods described by Malavolta et al. (1997). The $\mathrm{N}$ content was extracted by sulfur digestion and determined by the Kjedahl method. The $B$ was extracted by dry digestion and determined by the muffle method, and the other nutrients were extracted by nitric-perchloric digestion. The $P$ content was determined colorimetrically based on the development of the blue color by reducing the phospho-molybdic complex. The $\mathrm{K}, \mathrm{Ca}, \mathrm{Mg}$, $\mathrm{Mn}, \mathrm{Zn}, \mathrm{Cu}$ and Fe were determined by atomic absorption spectrophotometry and $\mathrm{S}$ by the barium sulfate turbidimetry.

\section{Accumulation of fresh matter, dry matter and nutrients in shoot biomass}

12 months after the cane-plant harvest, the first regrowth harvest was carried out. At this stage, the shoots of sugarcane located in the $2.4 \mathrm{~m}^{2}$ area were collected from the center of the plots. The samples were used to determine the accumulation of fresh matter, dry matter and nutrients in shoot biomass. Sampling was carried out in accordance with the methodology used by Silva et al. (2017a).

The accumulation of fresh matter was determined in the field by weighing the shoots of the plants found in $2.4 \mathrm{~m}^{2}$ area of each experimental plot using a scale. Afterwards, fresh matter yield per hectare $\left(\mathrm{t} \mathrm{ha}{ }^{-1}\right)$ was calculated. After weighing, the needles, leaves and stalks were ground in a forage chopper and sub-samples were removed to determine the wet mass. The sub-samples were dried in a forced air circulation oven at $65^{\circ} \mathrm{C}$ for $72 \mathrm{~h}$ to obtain dry matter, which we quantified after grinding in a Willey mill following the methodology of Malavolta et al. (1997). Shoot biomass was evaluated for $\mathrm{N}, \mathrm{P}, \mathrm{K}, \mathrm{Ca}, \mathrm{Mg}, \mathrm{S}, \mathrm{B}, \mathrm{Cu}, \mathrm{Fe}, \mathrm{Mn}$ and $\mathrm{Zn}$ contents, according to the methods described by Malavolta et al. (1997).

\section{Quality of sugarcane stalk and juice}

In order to analyze the quality of the stalks and the juice, 10 medium plants were collected in the center of each plot. These plants were cut and the husks were removed. Samples were passed through a forage chopper, pressed and the juice was analyzed for soluble solids content (oBrix), percentage of apparent sucrose in the juice (POL), fiber of the stalks, recoverable sugars and percentage of sucrose in the cane (PC), according to Fernandes (2000). 


\section{Statistical analysis}

The results were submitted to analysis of variance and when they were significant ( $p \leq 0.05)$, a polynomial regression study was carried out using Sisvar software (Ferreira, 2011)

\section{Conclusion}

There was a significant effect of fertilization, both in leaf content and in shoot biomass concentration, only for $\mathrm{N}$, Fe and $\mathrm{Mn}$ in the leaves blades. There was a linear relationship between the increase in nitrogen and potassium concentration and increasing doses of fertilization. Nutritional deficiency occurred only for boron and copper, with values slightly below the minimum. There was no effect of fertilization on concentrations of soluble solids in juice ("Brix"), percentage of apparent sucrose in juice ("POL"), juice purity ("Purity"), percentage of apparent sucrose in the stalk ("PC") and total recoverable sugars per ton of industrial stalks (TRS). The values obtained for these industrial quality factors indicated excellent quality of sugarcane. Biomass yield was increased linearly with fertilization, yielding the regression equation of $Y=82.74+0.3394 x$, with $R^{2}$ of 0.9824 .

\section{Acknowledgements}

We would like to thank Programa de Desenvolvimento da Pecuária Leiteira da Região de Viçosa- MG (PDPL-RV) for the financial support and the fellowships conceded.

\section{References}

Barbosa MHP, Silveira LCl, Macedo GAR, Paes JMV (2007) Variedades melhoradas de cana-de-açúcar para Minas Gerais. Infor Agropec. 28 (239):20-24.

Bloom AJ The increasing importance of distinguishing among plant nitrogen sources (2015) Curr Opin Plant Biol. 25, 1016.

Caione G, Lange A, Benett CGS, Fernandes FM (2011) Fontes de fósforo para adubação de cana-de-açúcar forrageira no cerrado. Pesq Agropec Trop. 41(1): 66-73.

Calheiros AS, Oliveira MW, Ferreira VM, Barbosa GVS, Santiago AD, Aristides EVS (2012) Production of biomass, from sugar and protein in function of sugarcane varieties and phosphorous fertilization. Semina Cienc Agrar. 33(2), 809-818.

Canfield DE, Glazer AN, Falkowski PG (2010) The evolution and future of Earth's nitrogen cycle. Science 330, 192-196.

Cardin CA, Santos CHD, Escarmínio MA. (2016) Impacts of vinasse and methods of sugarcane harvesting on the availability of $\mathrm{K}$ and carbon stock of an Argisol. Rev Cer. 63(1), 95-102.

Clemente PRA, Bezerra BKL, Silva VSG, Santos JCMD, Endres $L$ (2017). Root growth and yield of sugarcane as a function of increasing gypsum doses. Pesq Agropec Trop. 47(1), 110-117.

Embrapa - Empresa Brasileira de Pesquisa Agropecuária (2009) Manual de análise química de solo, planta e fertilizantes. Embrapa, Brasília. p 627.

Embrapa - Empresa Brasileira de Pesquisa Agropecuária (2013) Sistema brasileiro de classificação de solos. Embrapa, Brasília. p 353.
Ernani PR, Ribeiro MFSS, Bayer C (2011) Modificações químicas em solos ácidos ocasionadas pelo método de aplicação de corretivos da acidez e de gesso agrícola. Scientia Agrícola, 58(4): 825-831.

Fernandes AC (2000) Cálculos na agroindústria da cana-deaçúcar. Stab, Piracicaba. p.193.

Fernandes AM, Queiroz AC, Lana RP, Pereira JC, Cabral LS, Vittori A, Pereira ES (2001) Estimates of the milk production by crossbred holstein cows, in accordance to CNCPS system, in diets containing sugar cane with different nutritive values R. Bras. Zootec., 30(4):13501357.

Ferreira DF (2011) Sisvar: a computer statistical analysis system. Cienc Agrotec. 35(6): 1039-1042.

Flores RA, Prado RM, Politi LS, Almeida TBF (2012) Potássio no desenvolvimento inicial da soqueira de cana crua. Pesq Agrop Trop. 42 (1):106-111.

Franco HCJ, Bologna IR, Faroni CE, Vitti AC, Trivelin PCO (2007) Acúmulo de macronutrientes em cana-de-açúcar em função da adubação nitrogenada e dos resíduos culturais incorporados ao solo no plantio. Bragantia. 66(4): 669-674.

Lima JD, Sakai RK, Aldrighi M (2012) Produção de biomassa e composição química de adubos verdes cultivados no Vale do Ribeira. Biosc. J. 28(5): 709-717.

Lima MLM, Mattos WRS (1993) Cana-de-açúcar na alimentação de bovinos leiteiros. Paper presented at the Simpósio sobre nutrição de bovinos, University of São Paulo, Piracicaba 77-105, 1993.

Malavolta E, Vitti GC, Oliveira AS (1997) Avaliação do estado nutricional das plantas. Associação Brasileira para Pesquisa da Potassa e do Fosfato, Piracicaba. 319 p.

Marschner P (2012) Mineral Nutrition of higher plants. 3rd edn. Elsevier, San Diego. 651 p.

Mendes LC (2006) Eficiência nutricional de cultivares de cana-de-açúcar. Dissertation, Universidade Federal de Viçosa, Viçosa.

Oliveira DC, Oliveira MW, Pereira MG, Gomes TCA, Silva VSG, Oliveira TBA (2017) Stalk productivity and quality of three sugarcane varieties at the beginning, in the middle, and at the end of the harvest. Afr J Agric Res. 12(4), 260269.

Oliveira ECA, Freire FJ, Oliveira RI, Freire, MBGS., Simões Neto DE, Silva SAMG (2010) Extração e exportação de nutrientes por variedades de cana-de-açúcar cultivadas sob irrigação plena. Rev Bras de Cien do Solo, 34(4): 13431352.

Oliveira MW, Freire FM, Macêdo GAR, Ferreira JJ (2007) Nutrição mineral e adubação da cana-de-açúcar. Inf Agropec, 28 (1), 30-43.

Oliveira MW, Silva VSG, Reis LS, Oliveira DC, Silva JCT (2014) Produção e qualidade de três variedades de cana-deaçúcar cultivadas no nordeste de Minas Gerais. Ciência Agrícola, 12 (1) 9-16.

Oliveira RI, Medeiros MRFA, Freire CS, Freire FJ, Simões Neto, DE, Oliveira ECA (2016) Nutrient partitioning and nutritional requirement in sugarcane. Aust J Crop Sci. 10(1):69-75.

Pereira LFM, Ferreira VM, Oliveira NG, Sarmento PLVS, Endres L, Teodoro I (2017) Sugars levels of four sugarcane genotypes in different stem portions during the maturation phase. An Acad Bras Ciênc. 89 (2) 1231-1242 
Pina, JC, Bono JA, Oliveira AK, Rufino RDS, Amorim DO (2015) Organic residues on rooting and yield of sugarcane in Typic Quartzipsamments soil. Rev Bras Eng Agríc Ambient. 19(7): 650-655.

Prado RM, Pancelli MA (2006) Nutrição nitrogenada em soqueiras e a qualidade tecnológica da cana-de-açúcar. Stab.25(2): 60-63.

Prellwitz WPV, Coelho FC (2011) Productivity of stalks, leaf area index and $\mathrm{N}$ accumulation in sugarcane ratoons intercropped with Crotalaria juncea L. Rev Cer. 58(6):773780.

Raij BV (2011) Fertilidade do solo e manejo de nutrientes. International Plant Nutrition Institute, Piracicaba. p.420
Salas M., Aumont G, Biessy G, Magnie E (1992) Effect of variety, stage of maturity and nitrate fertilization on nutritive value of sugarcane. Anim Feed Sci Technol. 39(3), 1992.

Silva DJ, Queiroz AC (2006) Análise de alimentos: métodos químicos e biológicos. UFV, Viçosa. p.235.

Silva VSG, Oliveira MW, Oliveira DC, Oliveira TBA, Pereira MG, Nogueira, CHC (2017a) Nutritional diagnosis of sugarcane varieties in a Yellow Oxisol during three agricultural seasons. Afr J Agric Res, 12(1), 50-57.

Silva VSG, Oliveira MW, Oliveira TBA, Mantovanelli BC, Silva $\mathrm{ACl}$, Soares ANR, Clemente PRA (2017b) Leaf area of sugarcane varieties and their correlation with biomass productivity in three cycles. Afr J Agric Res, 12(7), 459-466.

Silva VSG, Oliveira MW, Silva AC, Silva AF, Galvão ER, Santana MB (2017c) Agro-industrial quality in plant, first and second ratoon crops of sugarcane varieties Aust J Crop Sci. 11(09), 1216-1220. 